\title{
Detection of Mycobacterium avium subspecies paratuberculosis in formula milk from Bogor using PCR IS 900
}

\author{
Widagdo Sri Nugroho ${ }^{1,2}$, Mirnawati Sudarwanto ${ }^{3}$, Denny Widaya Lukman ${ }^{3}$, Rochman Naim ${ }^{3}$, \\ Abdulwahed Ahmed Hassan ${ }^{4}$, Ewald Usleber ${ }^{4}$
}

\begin{abstract}
Abstrak
Penyakit Crohn (CD) yang menjadi masalah penting bagi kesehatan masyarakat di negara maju, memiliki kemiripan gejala klinis dan gambaran patologis dengan penyakit Johne's disease (JD) pada hewan ruminasia yang terinfeksi Mycobacterium avium subspecies paratuberculosis (MAP). Beberapa penelitian di Eropa, Amerika Serikat dan Australia menunjukkan keterkaitan antara MAP, CD, dan JD dengan produk susu dan olahannya termasuk susu bubuk. Masyarakat Indonesia mengonsumsi susu sapi dan produk olahannya yang berasal dari dalam negeri maupun impor. Adji pada tahun 2004 menemukan beberapa sapi perah lokal terinfeksi MAP lewat pemeriksaan serologis dan hal ini dapat menjadi permasalahan serius pada peternakan sapi perah maupun pada kesehatan manusia di masa mendatang. Penelitian ini bertujuan mendeteksi MAP di dalam susu formula lanjutan. Lima puluh sampel yang berasal dari 5 pabrik diambil dari supermarket di wilayah Bogor. Metode reaksi rantai polimerase (PCR) dengan menggunakan sekuen insersi 900 (IS 900) sebagai primer dan biakan pada media Herrold's egg yolk diperkaya mycobactin J (HEYM J) sebagai baku emas digunakan dalam penelitian ini. Tidak ada bakteri MAP yang tumbuh setelah diikubasi selama 20 minggu, demikian juga tidak ada uji positif dari pemeriksaan PCR IS 900. Meskipun tidak ada sampel positif dalam penelitian ini, perlu dilakukan penelitian lanjutan yang menyeluruh, jumlah sampel yang lebih banyak dan bervariasi serta pada manusia, untuk menyediakan data MAP yang lengkap di Indonesia. (Med J Indones 2008; 17: 183-7)
\end{abstract}

\begin{abstract}
Abctract
Crohn's disease (CD) that becomes a public health concern in developed countries shows similarities in clinical signs and pathological features with Johne's disease (JD) in ruminants infected by Mycobacterium avium subspecies paratuberculosis (MAP). Few researches conducted in Europe, the USA, and Australia showed relationships between MAP, CD, JD and dairy products. Indonesians consume milk and diary products from domestic and imported source. Adji in 2004 found some domestic dairy cows that were seropositive for MAP, and this could be a serious problem in dairy farm animals and human health in the future. The aim of this study was to detect MAP in the growing up formula milk. Fifty samples from five established factories were taken from supermarkets in Bogor. Polymerase chain reaction method (PCR) with insertion sequence (IS) 900 as primer and culture in Herrold's egg yolk media with mycobactin J (HEYM J) as a gold standard were used in this study. Neither MAP grew up in HEYM J medium after 20 weeks of culture period nor positive samples by PCR IS 900 were found. Although there were no positive samples found in this study, further extensive and comprehensive studies on MAP should be done with more and varied samples, as well as in human to provide data on MAP in Indonesia. (Med J Indones 2008; 17: 183-7)
\end{abstract}

Keywords: Crohn's disease, dairy cow, growing up formula milk.

In the last decade, Mycobacterium avium subspecies paratuberculosis (MAP) infection is a public health concern in Europe and USA. The bacteria is suspected

\footnotetext{
${ }^{1}$ Faculty of Veterinary Medicine, Gadjah Mada University, Yogyakarta, Indonesia

2 Post Graduate School of Bogor Agricultural University, Bogor, Indonesia

3 Faculty of Veterinary Medicine, Bogor Agricultural University, Bogor, Indonesia

${ }^{4}$ Milchwissenschaften Institut für Tierärzliches Nahrungsmittelkunde der Justus-Liebig Universitat, Giessen, Germany
}

as one of the etiological factors of granulomatous enteritis in human known as Crohn's disease (CD). ${ }^{1}$ This inflammatory disorder shows many similarities to Johne's disease (JD) in ruminants infected by MAP. ${ }^{2}$ Both diseases had an impact on global economy and human health. Europe Scientific Committee on Animal Health and Animal Welfare reported that Sweden spent over $€ 40$ million on patients with CD in 1994 and the incidence rate in Europe reached 5.6 cases per 100.000 persons per year. ${ }^{3}$ On the other side, JD had caused financial lost about $\$ 1.5$ billion per year in the United 
States of America (USA) dairy farm in $1998^{4}$ and up to $70 \%$ of dairy farm animals suffered from the disease in some European countries, USA, and Canada. ${ }^{3}$

The possibility link between MAP, JD, and CD has encouraged some researchers to explore the information to recognize the problem. The investigation covered animals (cattle, sheep, goat etc), animal products (raw milk, pasteurized milk, cheese, etc.), human, bacterial characteristics, etc. Animals might shed MAP in their milk even in subclinical infection. Human exposure to MAP through dairy products has become an issue of concern despite the fact that there is no conclusive evidence to support the association of the pathogen with CD. ${ }^{5}$ Some data showed that MAP could be detected in fresh milk and milk products. The bacteria was detected in fresh milk, pasteurized milk, cheese, and infant formula milk in United Kingdom, Ireland, USA, and Czech Republic. ${ }^{6-9}$ In Australia, MAP cattle strain could be isolated from human breast milk. ${ }^{10}$ Hence, it is conceivable that MAP might be transmitted to human by the consumption of contaminated food. ${ }^{11}$

All evidence menthioned above showed that MAP has become a public health concern in developed countries; meanwhile in Indonesia there is very poor information about MAP. The presence of MAP in Indonesia was reported by $\mathrm{Adji}^{12}$ who detected 3 seropositive among 121 dairy cows (1.67\%) by ELISA in West Java Region, but only one MAP suspect culture grew up in HEYM $\mathrm{J}$ medium. This is a serious situation because there is no valid data on MAP in cattle, dairy products, milk products, other food-animal products, and human. The information should become our concern since all of the national dairy products are marketed directly to people and milk industries. In addition, the factories should import raw milk and other ingredients from European countries or Australia to fulfill national demand. The concerns of MAP infection in human increased because most of the milk industries have the children as the main target of their market, and they are at the high risk age to any diseases. Unfortunately, in most of the MAP infected men, the infection was started at childhood and the clinical symptoms appeared in the next 5-10 years after they got infected.

Detection of viable MAP using culture and MAP DNA by PCR method in growing-up formula milk in Indonesia have never been done before. The aim of the present study was to detect the MAP in growing up formula milk taken from supermarkets in Bogor.

\section{METHODS}

\section{Collection of samples}

\section{Milk formula}

Fifty cartons of growing up formula milk (120 g-200 g/ pack) for children, were collected on August 2006. All samples produced by 5 different established factories were purchased in the supermarkets throughout the Bogor region.

\section{Procedures}

\section{Detection of MAP in formula milk by culture}

Preparation of milk samples: Twenty (20) grams of each sample was dissolved in sterile aquadest to make $100 \mathrm{ml}$ milk. The sample was shaken manually to homogenize it. The total volume $(100 \mathrm{ml})$ was directly transferred to two sterile glass tubes (each tube contained $50 \mathrm{ml}$ milk) of Heraeus Multifuge 3-SR Centrifuge (Kendro Laboratory products, Osterode, Germany). The samples were centrifuged at 2500x $g$ for $15 \mathrm{~min}$. at $4{ }^{\circ} \mathrm{C}$, the cream and whey fractions were decanted and the pellet of each tube was resuspended in sterile aquadest to make one $\mathrm{ml}$ suspension, mixed well and pooled together. The total volume $(2 \mathrm{ml})$ of the last suspension was divided into two equivalent parts; one $\mathrm{ml}$ for culture and the other one for DNA detection by PCR method.

Decontamination and culture process: one $\mathrm{ml}$ of the suspension mentioned above was transferred into a sterile glass tube and treated with $10 \mathrm{ml}$ of $0.75 \%$ hexadecilpyridinium chloride (HPC) for 5 hours in room temperature for decontamination. Further, the suspension was centrifuged at $2500 \mathrm{x} g$ for $15 \mathrm{~min}$, the supernatant was carefully decanted and the pellet was resuspended in $500 \mu \mathrm{l}$ sterile PBS containing $0.05 \%$ Tween 20 (PBS-T) (Sigma, Steinheim, Germany). Then, $250 \mu \mathrm{l}$ were inoculated in Herrold's egg yolk medium containing mycobactin J agar (HEYM J medium). The medium was incubated at $37^{\circ} \mathrm{C}$ for 20 weeks to grow the bacteria. The suspected colonies in HEYM J medium were stained with Ziehl-Neelsen acid fast stain (Becton Dickinson) to confirm the Mycobacterium species.

\section{Detection of MAP DNA in growing-up milk samples by PCR}

DNA extraction from growing-up formula milk samples: $500 \mu \mathrm{l}$ of the suspension described above were used for DNA extraction. The sample was transferred to a 
$2 \mathrm{ml}$ reaction tube and centrifuged at $10.000 \mathrm{x} g$ for 30 min, the supernatant was discarded, and the pellet was resuspended in $400 \mu 1$ of TE lysis buffer. The mixture was shaken in a vortex vigorously and incubated for $5 \mathrm{~min}$. at $-80^{\circ} \mathrm{C}$, and then immediately put in a water bath for $1 \mathrm{~min}$. at $95^{\circ} \mathrm{C}$. The chilling/heating steps were repeated twice. Finally, the sample was incubated in a water bath at $80^{\circ} \mathrm{C}$, for $20 \mathrm{~min}$., and the sample was cooled to $4^{\circ} \mathrm{C}$, then $50 \mu \mathrm{l}$ of proteinase $\mathrm{K}$ and 400 $\mu 1$ AL lysis buffer (Qiagen, Hilden, Germany) were added, then shaked in a vortex shortly, and incubated over night at $56^{\circ} \mathrm{C}$. From the last mixture, the DNA was extracted by using DNeasy ${ }^{\mathbb{R}}$ tissue kit according to the manufacturer's instruction.

PCR amplification of IS900 specific DNA: The PCR to amplify IS900 specific DNA fragments of MAP used a set of oligonuclotide primers TJ1/TJ2 described by Bull et al. ${ }^{1}$ The PCR amplification of IS900 was performed in $50 \mu 1$ reaction mixtures in 0.2 $\mathrm{ml}$ reaction tubes containing the following reaction mixtures: $1.5 \mu \mathrm{l}$ of each primers $(10 \mathrm{pmol} / \mu \mathrm{l}), 1.5 \mu \mathrm{l}$ dNTP-mix (10 mmol/ $\mu \mathrm{l})$ (MBI Fermentas, St. LeonRot, Germany), $5 \mu$ l GeneAmp 10x PCR Gold Buffer (150 mM Tris-HCL, $500 \mathrm{mM} \mathrm{KCL}, \mathrm{pH}$ 8.0) (Applied Biosystem, Darmstadt, Germany), $3.0 \mu 1 \mathrm{MgCl}_{2}(25$ $\mathrm{mM}$ ) (Applied Biosystem), $0.35 \mu 1$ AmpliTaq Gold ${ }^{\circledR}$ polymerase (5 U/ $\mu 1$, Applied Biosystem), $32.15 \mu 1$ sterile aquadest, and 5.0 $\mu \mathrm{l}$ DNA template was added later. The PCR amplifications condition for the IS900 was carried out for 1 cycle at $95{ }^{\circ} \mathrm{C}$ for $10 \mathrm{~min}$. and then followed by 40 cycles of $95^{\circ} \mathrm{C}$ for $1 \mathrm{~min} ., 58^{\circ} \mathrm{C}$ for $1 \mathrm{~min}$., and $72^{\circ} \mathrm{C}$ for $3 \mathrm{~min}$., followed by a final cycle at $72^{\circ} \mathrm{C}$ for $7 \mathrm{~min}$. in $i$ Cycler-Biorad thermocycler (Biorad, Munich, Germany). PCR products of IS900 $(13 \mu 1)$ were mixed with $2 \mu 1$ orange loading dye solution (MBI Fermentas) and together with a marker of 100 bp DNA ladder (MBI Fermentas, St. Leon-Rot, Germany) were separated by $2 \%$ agarose gel electrophoresis (Biozym, Hessisch-Oldendorf, Germany) at $120 \mathrm{~V}$ in $1 \mathrm{x}$ TAE buffer $(0.04 \mathrm{~mol} / 1 \mathrm{Tris}, 0.001 \mathrm{~mol} / \mathrm{l}$ EDTA, pH 7.8). After electrophoresis, the gels were stained for $5 \mathrm{~min}$. with $5 \mu \mathrm{l} / \mathrm{ml}$ ethidium bromide solution (Sigma, Taufkirchen, Germany), and visualized under a UV (245 nm) trans-illuminator (Biorad).

\section{RESULT}

There were no MAP that grew up after 20 weeks incubation in culture method using HEYM J medium and no MAP DNA was detected by PCR IS 900 (Table 1).
Table 1. Culture and PCR results to detect MAP in formula milk from Bogor, Indonesia

\begin{tabular}{ccccc}
\hline Producer & \multicolumn{2}{c}{ HEYM } & \multicolumn{2}{c}{ PCR IS 900 } \\
\cline { 2 - 5 } (no of Sample) & + & - & + & - \\
\hline $1(10)$ & 0 & 10 & 0 & 10 \\
$2(10)$ & 0 & 10 & 0 & 10 \\
$3(10)$ & 0 & 10 & 0 & 10 \\
$4(10)$ & 0 & 10 & 0 & 10 \\
$5(10)$ & 0 & 10 & 0 & 10 \\
\hline Total $(50)$ & 0 & 50 & 0 & 50 \\
\hline
\end{tabular}

\section{DISCUSSION}

Mycobacterium avium subspecies paratuberculosis is an acid-fast bacillus, strictly aerobic, grows slowly, and depends on exogenous mycobactin for in vitro growth. In vivo MAP is a facultative intracellular pathogen, invades bovine and other ruminant intestinal epithelial cells and survives in sub epithelial macrophages. ${ }^{13}$ The major membrane protein has a role in initiation of infection in vivo. ${ }^{14}$

Thermal resistance is the important character of MAP giving it a potential-role in food-borne disease. Three proteins have been identified to have possible association with such ability. All of them were identified as GroES heat shock protein, antigen 85 complex B (fibrinogen-binding protein) and alpha antigen that may be associated with heat resistance of MAP. ${ }^{15}$

The efforts to control JD and CD have been hampered by lack of sensitive techniques for the detection of asymptomatic paratuberculosis. Faecal culture for MAP is considered as a gold standard for diagnosis, but fastidious nature of the organism along with its slow growth characteristics makes the isolation of MAP a time-consuming process. ${ }^{16}$

Hence, some researchers still found MAP at the end products of pasteurized cow milk. Grant et al. found that MAP in naturally infected milk were capable to survive in commercial high temperature short time (HTST) pasteurization if they were present in raw milk in sufficient number. ${ }^{7}$ Those arguments were supported by some field data which detected MAP in some milk and milk products.

In 1990, Vary et al. introduced PCR technique to detect insertion sequence 900 (IS 900), a MAP DNA fragment. The primer used is specific sequence to identify MAP among other Mycobacterium avium complex. ${ }^{2}$ The most 
critical issue in using PCR IS 900 is false positive results, when it detects other MAP sequences with similarity to the IS 900 element. Yet Semret et al. ${ }^{17}$ countered that issue and proved that IS 900 consistently revealed polymorphisms at four different loci in reference to the genome sequence of MAP strain K10. Until now PCR IS 900 is very efficient and helpful to detect MAP in some materials.

Using PCR and culture method, MAP could be detected in commercially pasteurized cow milk in the United Kingdom. ${ }^{18}$ Surveillance in bulk raw and commercial pasteurized cow milk in the Republic of Ireland found that $12.9 \%$ of 389 raw milk and $9.8 \%$ of 357 commercial pasteurized milk contained MAP DNA, but only very few cells could be cultured. ${ }^{9}$ Mycobacterium avium subspecies paratuberculosis was also detected in cheddar cheese. ${ }^{6}$ Thus, it is rational to consider that an infectious etiology for Crohn's disease might be acquired through ingestion of food stuffs such as milk and milk products.

Crohn's disease is an inflammatory bowel disease or accurately an inflammatory syndrome. The aetiology of $\mathrm{CD}$ is thought to be multifactors involving genetic susceptibility, undefined environmental triggers and immune-mediated tissue injury. ${ }^{11}$ There are three main theories for the aetiology of CD: autoimmune theory, the immune deficiency theory and the microbial theory. Eventhough the most widely published as the cause of the syndrome is the autoimmune theory, ${ }^{19}$ many researchers and publications about $\mathrm{CD}$ revealed that MAP was detected in CD patients that was found by Dlazil in 1913 for the first time. ${ }^{3}$ Hermon-Taylor et $\mathrm{al}^{20}$ identified MAP by PCR IS 900 primer in the cervical lymph nodes of a 7-year old boy with scrofula and five years later the boy developed classical illness of CD. Whittington et al. ${ }^{10}$ also identified a MAP catlle strain in CD patients in Australia. The MAP was also detected by PCR in breast milk of 2 lactating CD patients meanwhile there were no positive result from the breast milk of 5 healthy mothers. ${ }^{21}$ Similar to those data, Bull et al. ${ }^{1}$ detected MAP in 34 of $37(92 \%)$ patients with CD and 9 of 34 (26\%) control without CD using PCR IS 900. Naser et al. ${ }^{22}$ detected MAP in blood in 14 of 28 CD patients, 2 of ucerative colitis patients but none of fivteen persons without inflamatory bowel disease. All those data contribute to the opinions that MAP is highly suspected as etiology of Crohn's disease.

Our study showed no positive MAP using culture and PCR IS 900 assay. However, different result was showed by Hruska et al. ${ }^{8}$ who found that 25 and 18 out of 51 samples of powdered infant milk in Czech Republic were positive MAP by PCR IS 900 and f57 real-time PCR respectively. Our result is a preliminary data about MAP in milk products. Therefore, it is suggested to continue detecting MAP in dairy catlle, raw milk and milk products, and other food-animal products as an anticipated action to avoid the spreading of $\mathrm{CD}$ in Indonesia. Comprehensive and sustainable study on MAP should be done with bigger sample size in order to provide a real figure of MAP in cattle, milk and milk products especially for children. Target samples can include beef cattle, sheep, goat, and soil or water around the farm. Last but not least, investigation should also be conducted in human. Indonesia is in the third place in the world for tuberculosis and leprae. Both diseases are caused by Mycobacterium tuberculosis and Mycobacterium leprae that come from the same family as MAP. These facts support the suspicion that MAP may exist in Indonesia but no one concern to investigate it. Detection of MAP in human will be useful if the research target is focused on the patients who suffer crohn's disease, infectious bowel disease, colitis or other enteric inflamatory disease. All of those investigations will give significant contribution in providing the data about MAP in Indonesia comprehensively and completely.

In conclusion, there was no MAP found in formula milk samples in Bogor, Indonesia in this preliminary investigation. However the study should be continued with more targets and bigger sample size to provide comprehensive and complete data about MAP in Indonesia.

\section{Acknowledgement}

We thank to the Directorate General of Higher Education, National Education Department, Republic of Indonesia for financial support to continue post graduate study for the first author, and Deutsche Akademische Austauschdienst (DAAD) to support the research through the sandwich program in Germany.

\section{REFERENCES}

1. Bull TJ, McMinn EJ, Boumedine KS, Skull A, Durkin D, Neild P, et al. Detection and verification of Mycobacterium avium subsp. paratuberculosis in fresh ileocolonic mucosal biopsy specimens from individuals with and without crohn's disease. J Clin Microbiol. 2003; 41(7): 2915-23. 
2. Harris NB, Barletta RG. Mycobacterium avium subsp. paratuberculosis in veterinary medicine. Clin Microbiol Rev. 2001;14(3): 489-512.

3. European Commission, Directorate-General Health \& Consumer Protection. Possible links between crohn's disease and paratuberculosis. Report of the Scientific Committee Health and Animal Welfare, 2000 April.

4. Stabel JR. Johne's disease: a hidden threat. J Dairy Sci. 2002;81:283-8.

5. Hermon-Taylor, Bull TJ. Crohn's disease caused by Mycobacterium avium subsp. paratuberculosis: a public health tragedy whose resolution is long overdue. JM Microbiol. 2002;51: 3-6.

6. Donaghy JA, Totton NL, Rowe MT. Persistence of Mycobacterium paratuberculosis during manufacture and ripening of cheddar cheese. Appl Environ Microbiol. 2004;70(8):4899-905.

7. Grant IR, Ball HJ, Rowe MT. Incidence of Mycobacterium paratuberculosis in bulk raw and commercially pasteurized cows milk from approved dairy processing establishments in the United Kingdom. Appl Environ Microbiol. 2002; 68(5):2428-35.

8. Hruska K, Bartos M, Kralik P, Pavlik I. Mycobacterium avium subsp. paratuberculosis in powdered infant milk: paratuberculosis in catlle-the public health problem to be solved. Vet Med Czech. 2005;50(8): 327-35.

9. O'Reilly CE, O'Connor L, Anderson W, Harvey P, Grant IR, Donaghy J, et al. Surveillance of bulk raw and commercially pasteurized cows' milk from approved Irish liquid-milk pasteurization plants to determine the incidence of Mycobacterium paratuberculosis. Appl Environ Microbiol. 2004;70(9):5138-44.

10. Whittington RJ, Hope AF, Marshall DJ, Taragel CA, Marsh I. Molecular epidemiology of Mycobacterium avium subsp. paratuberculosis: IS900 restriction fragment length polymorphism and is 1311 polymorphism analyses of isolates from animals and human in Australia. J Clin Microbiol. 2000;38(9):3240-8.

11. Chamberlin W, Graham DY, Hulten K, El-Zimaity MT, Schwartz MR, Naser S, et al. Review article: Mycobacterium avium subsp. paratuberculosis as one cause of Crohn's diseases. Aliment Pharmacol Ther. 2001;15: 337-46.

12. Adji RS. Isolasi dan uji serologi terhadap Mycobacterium paratuberculosis pada sapi perah [Isolation and serology test to Mycobacterium paratuberculosis in dairy cattle (INA)]. Prosiding Seminar Nasional Teknologi Peternakan dan Veteriner; 2004 August 4-5; Jakarta, Indonesia. Jakarta: Pusat Penelitian dan Pengembangan Peternakan. Badan Penelitian dan Pengembangan Pertanian. Departemen Pertanian; 2004.p.281-4.

13. Bannantine JP, Stabel JR. Killing of Mycobacterium avium subsp. paratuberculosis within macrophages. BMC Microbiology [serial on the internet] 2002; [cited 2005 July 15] (about 7P.) Available from: http://www. biomedcentral. com/1471-2180/2/2.

14. Bannantine JP, Huntley JF, Miltner E, Stabel JR, Bermudez LE. The Mycobacterium avium subsp. paratuberculosis 35 $\mathrm{kDa}$ protein plays a role in invasion of bovine epithelial cells. Microbiol. 2003; 149:2061-9.

15. Sung N, Takayama K, Collins MT. Possible association of GroES and antigen 85 protein with heat resistance of Mycobacterium paratuberculosis. Appl Environ Microbiol. 2004;70(3):1688-97.

16. Hermon-Taylor J, Bull TJ, Sheridan JM, Cheng J, Stelakis ML, Sumar N. Causation of Crohn's disease by Mycobacterium avium subsp. paratuberculosis. Can J Gastroent. 2000;14:521-39.

17. Semret M, Turenne C, Behr MA. Insertion sequence IS 900 revisited. J Clin Microbiol. 2006;44(3):1081-3.

18. Grant IR, Hitchings EI, McCartney A, Ferguson F, Rowe MT. Effect of commercial-scale high-temperature, shorttime pasteurization on the viability of Mycobacterium paratuberculosis in naturally infected cows' milk. Appl Environ Microbiol. 2002; 68(2):602-7.

19. Chamberlin WM, Naser SA. Integrating theories of the etiology of Crohn's disease: questioning the hypotheses. Med Sci Monit. 2006; 12(2):RA27-33.

20. Hermon-Taylor J, Barnes N, Clarke C, Finlayson C. Grand round: Mycobacterium paratuberculosis cervical lymphadenitis, followed five years later by terminal ileitis similar to Crohn's disease. BMJ. 1998;316:449-53

21. Naser SA, SchwartzD, Shafran I. Isolation of Mycobacterium avium subsp. paratuberculosis from breast milk of Crohn's disease patients. Am J Gastro. 2000;95(4):1094-5.

22. Naser SA, Ghobrial G, Romero C, Valentine JF. Culture of Mycobacterium avium subspecies paratuberculosis from the blood of patients with Crohn's disease. Lancet. 2004;364:1039-44. 